\title{
PENGARUH DOSIS PUPUK UREA TERHADAP PERTUMBUHAN KANGKUNG DARAT (Ipomoea
} reptans poir.)

\section{THE INFLUENCE OF UREA FERTILIZER DOSAGE ON GROWTH OF KALE LAND (Ipomoea reptans pir,)}

\author{
Mahrus dan Ahmad Raksun \\ Program Studi Pendidikan Biologi FKIP Universitas Mataram, Mataram, Indonesia \\ Email: mahrus@unram.ac.id
}

Diterima: 11 November 2019. Disetujui: 3 Desember 2019. Dipublikasikan: 10 Juni 2020

\begin{abstract}
Abstrak. Penelitian tentang pengaruh dosis pupuk urea terhadap pertumbuhan kangkung darat sudah dilakukan di Desa Bajur Kecamatan Labuapi Kabupaten Lombok Barat. Dalam penelitian ini digunakan rancangan acak lengkap dengan 4 ulangan. Dosis pupuk urea terdiri atas 5 level yaitu $\mathrm{U}_{0}=0$ gram pupuk urea per $10 \mathrm{~kg}$ tanah (kontrol), $\mathrm{U}_{1}=0,5$ gram pupuk urea per $10 \mathrm{~kg}$ tanah, $\mathrm{U}_{2}=1$ gram pupuk urea per $10 \mathrm{~kg}$ tanah, $\mathrm{U}_{3}=1,5$ gram pupuk urea per $10 \mathrm{~kg}$ tanah dan $\mathrm{U}_{4}=2$ gram pupuk urea per10 $\mathrm{kg}$ tanah. Parameter pertumbuhan yang diukur adalah tinggi batang, diameter batang, panjang helaian daun dan lebar helaian daun. Data hasil penelitian dianalisis menggunakan analisis sidik ragam dan uji lanjut dengan Uji Beda Nyata Terkecil. Hasil penelitian menunjukkan bahwa (1) Perbedaan dosis pupuk urea berpengaruh nyata terhadap tinggi batang, panjang helaian daun dan lebar helaian daun tetapi tidak berpengaruh nyata terhadap diameter batang kangkung darat, (1) Dosis optimum pupuk urea untuk tanaman kangkung darat adalah 1,5 gram per $10 \mathrm{~kg}$ tanah
\end{abstract}

Kata-kata kunci: pupuk urea, pertumbuhan kangkung darat

Abstract. Research on the effect of urea fertilizer dosage on the growth of kale land has been carried out in Bajur Village, Labuapi District, West Lombok Regency. In this study a complete randomized design with 4 replications were used. The dosage of urea fertilizer consists of 5 levels, $\mathrm{U}_{0}=0$ gram urea fertilizer per $10 \mathrm{~kg}$ of soil (control), $\mathrm{U}_{1}=0.5$ gram urea fertilizer per $10 \mathrm{~kg}$ of soil, $\mathrm{U}_{2}=1$ gram urea fertilizer per $10 \mathrm{~kg}$ of soil, $\mathrm{U}_{3}=$ 1.5 gram urea fertilizer per $10 \mathrm{~kg}$ of soil and $\mathrm{U}_{4}=2$ grams urea fertilizer per $10 \mathrm{~kg}$ of soil. The growth parameters measured were stem height, stem diameter, leaf blade length and leaf blade width. The research data were analyzed using analysis of variance and further tests with the Least Significant Difference Test. The results showed that (1) the difference in dose of urea fertilizer significantly affected the stem height, leaf blade length and leaf blade width but did not significantly affect the diameter of kale lang steam, (1) The optimum dose of urea fertilizer for kale land was 1,5 grams per $10 \mathrm{~kg}$ of soil.

Key Words: urea fertilizer, growth of kale land

\section{PENDAHULUAN}

Ketersediaan unsur hara pada media tanamam merupakan salah satu faktor yang sangat menentukan terhadap pertumbuhan dan produksi tanaman. Upaya meningkatkan unsur hara dapat dilakukan dengan pemupukan tanaman baik dengan pupuk organik maupun pupuk sintetik. Jenis pupuk organik yang sering digunkan oleh masyarakat adalah pupuk kompos. Selanjutnya pupuk sintetik yang sering digunakan adalah pupuk NPK, KCL dan urea.

Penggunaan pupuk urea pada tanaman kangkung darat masih jarang dilakukan masyarakat khususnya di Pulau Lombok. Penggunaan pupuk urea pada berbagai tanaman lainnya menunjukkan bahwa pupuk urea dapat meningkatkan pertumbuhan dan hasil panen tanaman. Hasil penelitian [12] menunjukkan bahwa berbagai dosis dan cara aplikasi pupuk urea berpengaruh terhadap produksi tanaman sawi. Produksi tertinggi terdapat pada dosis $200 \mathrm{ppm}$. Cara aplikasi dicampur lebih baik daripada disebar dalam meningkatkan produksi tanaman sawi. Jika urea dicampur dosis optimum pupuk urea adalah $117 \mathrm{ppm}$ dan cara aplikasi di permukaan tanah dosis optimum pupuk urea adalah $190 \mathrm{ppm}$

Selain itu disimpukan pula bahwa pemberian pupuk urea $0.9 \mathrm{~g}$ sangat nyata dapat meningkatkan pertumbuhan tanaman bayam cabut putih, terlihat dari berat kering total tanaman sebesar 3,98g atau meningkat sebesar 437,83\% dibanding kontrol [6]. Dosis pupuk urea berpengaruh sangat nyata terhadap jumlah anakan pada umur $60 \mathrm{HST}$, berpengaruh nyata terhadap jumlah anakan 45 hst tanaman padi. Pertumbuhan dan hasil tanaman yang terbaik dijumpai pada perlakuan pupuk Urea $0.65 \mathrm{~g}$ per pot $\left(200 \mathrm{~kg} \mathrm{ha}^{-1}\right)$ [1]

Berdaskan uraian diatas maka peneliti melakukan penelitian tentang pengaruh dosis pupuk urea terhadap pertumbuhan kangkung darat. Tujuan penelitian ini adalah untuk mengetahui: (1) pengaruh dosis pupuk urea terhadap pertumbuhan 
kangkung darat, (2) dosis optimum pupuk urea yang perlu diberikan agar kangkung darat dapat tumbuh optimal.

\section{BAHAN DAN METODE}

Bahan-bahan yang digunakan adalah benih kangkung darat, tanah sawah, pupuk urea dan air. Selanjutnya alat-alat yang digunakan adalah pot plastik, gelas ukur, timbangan, dan meteran. Penelitian dilakukan dengan tahapan-tahapan: (1) mengeringkan tanah sawah pada terik matahari, (2) mengayak tanah untuk memisahkannya dari kerikil dan sampah, (3) memasukkan media tanah kedalam pot plastik sebanyak $10 \mathrm{~kg}$ per pot plastik, (4) menyiram tanah dalam pot dengan air sumur sampai basah secara merata, (5) menanam benih kangkung darat sebanyak 6 benih per pot plastik. (6) melakukan penjarangan dengan mencabut sebagian tanaman kangkung darat, hanya menyisakan 2 tanaman per pot yang dilakukan 5 hari setelah tanam, (7) memberi perlakuan pupuk urea, dan (8) melakukan pengukuran parameter pertumbuhan setelah tanaman berumur 15 hari [4]

Penelitian ini dilakukan di Desa Bajur Kecamatan Labuapi Kabupaten Lombok Barata. Dalam penelitian ini digunakan rancangan acak lengkap dengan 4 ulangan. Dosis pupuk urea terdiri atas 5 level yaitu $\mathrm{U}_{0}=0$ gram per pot (kontrol), $\mathrm{U}_{1}$ $=0,5$ gram per pot, $\mathrm{U}_{2}=1$ gram per pot, $\mathrm{U}_{3}=1,5$ gram per pot dan $\mathrm{U}_{4}=2$ gram per pot. Pemberian pupuk dilakukan dengan cara melarutkan pupuk urea pada 1 liter air dan diberikan pada tanaman kangkung darat pada umur 6 hari setelah tanam. Data kuantitatif hasi pengukuran parameter, dianalisis dengan analisis sidik ragam [3]

\section{HASIL DAN PEMBAHASAN}

Penelitian tentang pengaruh dosis pupuk urea terhadap pertumbuhan kangkung darat telah dilaksanakan di Desa Bajur Kecamatan Labuapi Kabupaten Lombok Barat Propinsi Nusa Tenggara Barat. Data hasil pengukuran tinggi batang kangkung darat pada gambar 1 menunjukkan bahwa tinggi batang tertinggi adalah $18 \mathrm{~cm}$ terdapat pada perlakuan $\mathrm{U}_{3}$ (perlakuan 1,5 gram pupuk urea per $10 \mathrm{~kg}$ tanah). Tinggi batang terendah adalah $14 \mathrm{~cm}$ terdapat pada perlakuan 0 kg pupuk urea (kontrol).

Hasil analisis sidik ragam pengaruh dosis pupuk urea terhadap tinggi batang kangkung darat menunjukkan bahwa dosis pupuk urea berpengaruh nyata terhadap pertumbuhan kangkung darat. Dosis optimum adalah 1,5 gram per tanaman. Hasil analisis sidik ragamnya terdapat pada tabel 2 .

Data pada gambar 2 adalah hasil pengukuran diameter batang kangkung darat yang dilakukan 16 hari setelah tanam. Diameter batang tertinggi adalah $4 \mathrm{~mm}$ terdapat pada perlakuan 1,5 pupuk urea per $10 \mathrm{~kg}$ tanah dan terendah adalah $3 \mathrm{~mm}$ terdapat pada perlakuan kontrol.

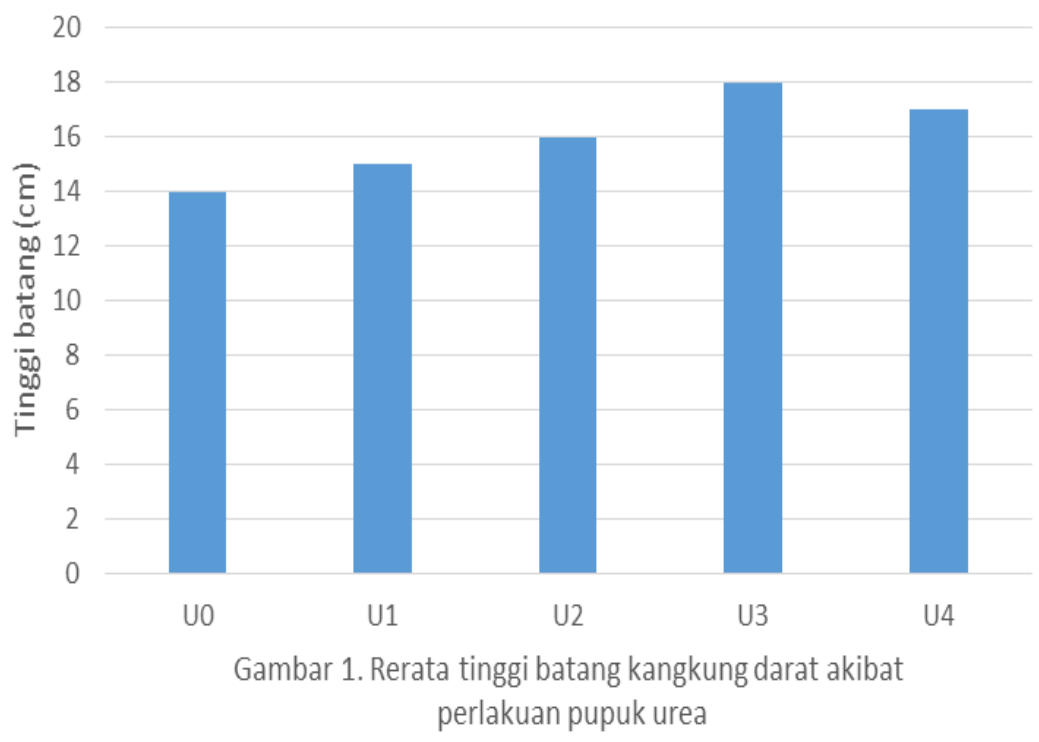

Tabel 1. Hasil analisis sidik ragam pengaruh dosis pupuk urea terhadap tinggi batang kangkung darat.

\begin{tabular}{llllll}
\hline $\begin{array}{l}\text { Sumber } \\
\text { Keragaman }\end{array}$ & DB & JK & KT & F. hitung & $\begin{array}{l}\text { F. tabel } \\
(0,05)\end{array}$ \\
\hline Perlakuan & 4 & 40 & 10 & 6,25 & 3,06 \\
Galat & 15 & 24 & 1,6 & & \\
Umum & 19 & 64 & & & \\
\hline
\end{tabular}




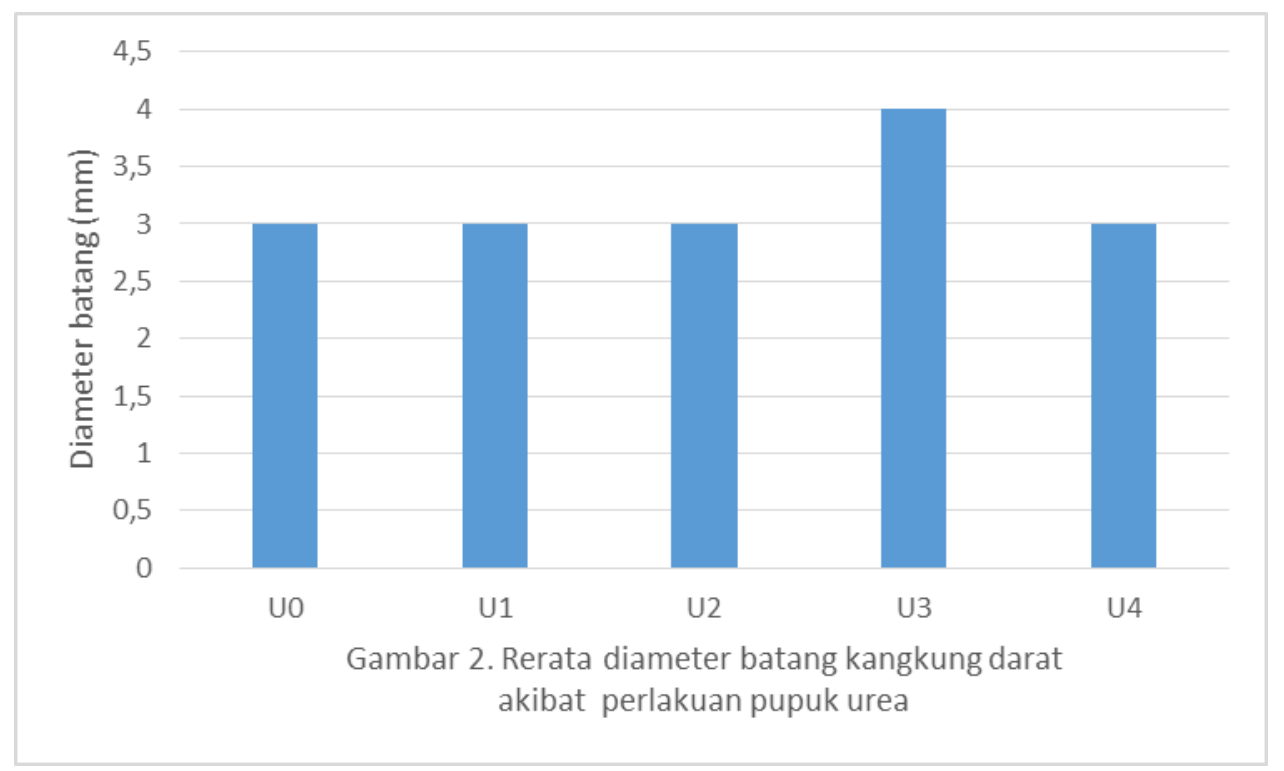

Tabel 2. Hasil analisis sidik ragam pengaruh dosis pupuk urea terhadap diameter batang kangkung darat.

\begin{tabular}{|l|l|l|l|l|l|}
\hline $\begin{array}{l}\text { Sumber } \\
\text { Keragaman }\end{array}$ & DB & JK & KT & F. hitung & $\begin{array}{l}\text { F. tabel } \\
(0,05)\end{array}$ \\
\hline Perlakuan & 4 & 3,2 & 0,8 & 0,015 & 3,06 \\
\hline Galat & 15 & 818 & 54,5 & & \\
\hline Umum & 19 & 821 & & & \\
\hline
\end{tabular}

Analis sidik ragam pengaruh pupuk urea terhadap diameter batang kangkung darat menunjukkan bahwa perlakuan pupuk urea tidak berpengaruh nyata terhadap diameter batang kangkung darat.

Data hasil pengukuran panjang helaian daun kangkung darat disajikan pada gambar 3 . Panjang helaian daun tertinggi adalah $116 \mathrm{~mm}$ terdapat pada perlakuan 1,5 gram pupuk urea per $10 \mathrm{~kg}$ tanah dan panjang helaian daun terendah adalah $106 \mathrm{~mm}$ terdapat pada perlakuan 0 gram pupuk urea.

Hasil analisis sidik ragam pengaruh dosis pupuk urea terhadap panjang helaian daun kangkung darat menunjukkan bahwa dosis pupuk urea berpengaruh nyata terhadap panjang helaian daun kangkung darat. Dosis optimum adalah 1,5 gram per $10 \mathrm{~kg}$ tanah. Hasil analisis sidik ragamnya terdapat pada tabel 3 .

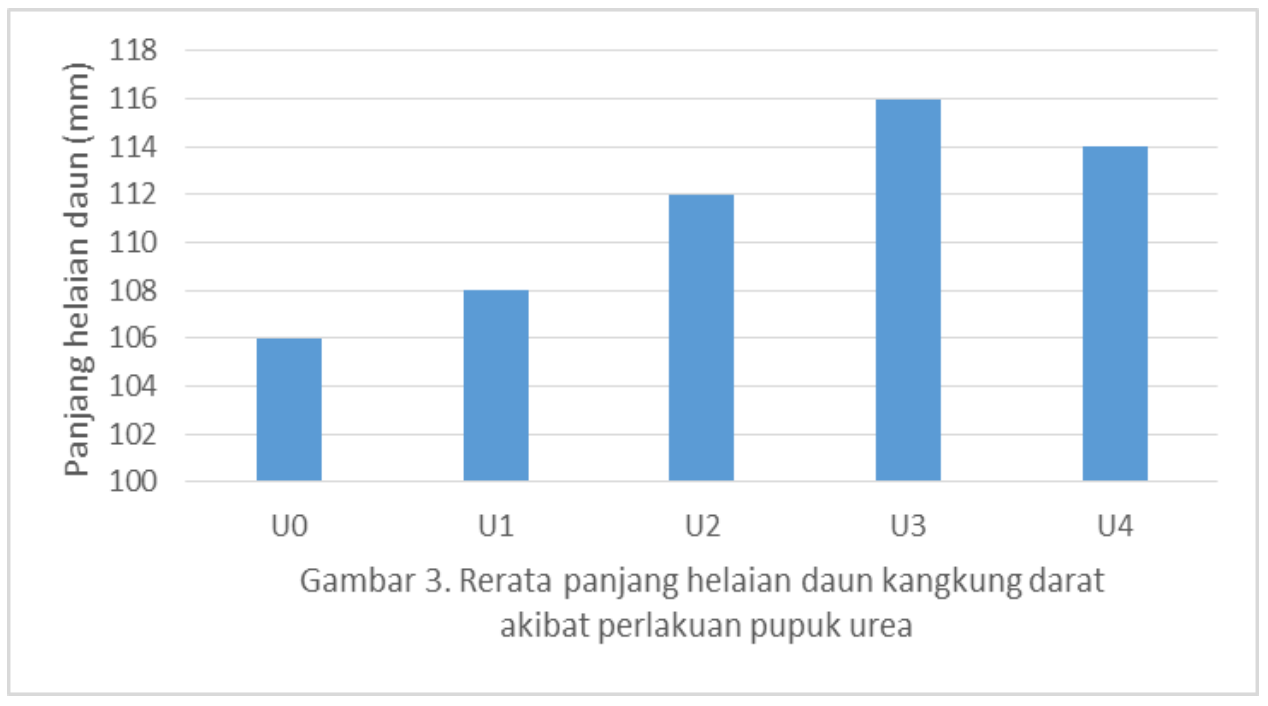


Tabel 3. Hasil analisis sidik ragam pengaruh dosis pupuk urea terhadap panjang helaian daun kangkung darat.

\begin{tabular}{|l|l|l|l|l|l|}
\hline $\begin{array}{l}\text { Sumber } \\
\text { Keragaman }\end{array}$ & DB & JK & KT & F. hitung & $\begin{array}{l}\text { F. tabel } \\
(0,05)\end{array}$ \\
\hline Perlakuan & 4 & 275 & 68,75 & 10,52 & 3,06 \\
\hline Galat & 15 & 98 & 6,53 & & \\
\hline Umum & 19 & 373 & & & \\
\hline
\end{tabular}

Rerata lebar helaian daun kangkung darat tertinggi adalah $36 \mathrm{~mm}$ terdapat pada perlakuan 1,5 gram pupuk urea per $10 \mathrm{~kg}$ tanah sedangkan rerata lebar helaian daun terendah adalah $28 \mathrm{~mm}$ terdapat pada tanaman kontrol. Data lebar helaian daun kangkung darat secara lengkap disajikan pada gambar 4.
Hasil analisis sidik ragam lebar helaian daun kangkung darat akibat perlakuan pupuk urea menunjukkan bahwa perlakuan pupuk urea berpengaruh nyata terhadap lebar helaian daun kangkung darat. Hasil analisis sidik ragaamnya disajikan pada tabel 4.

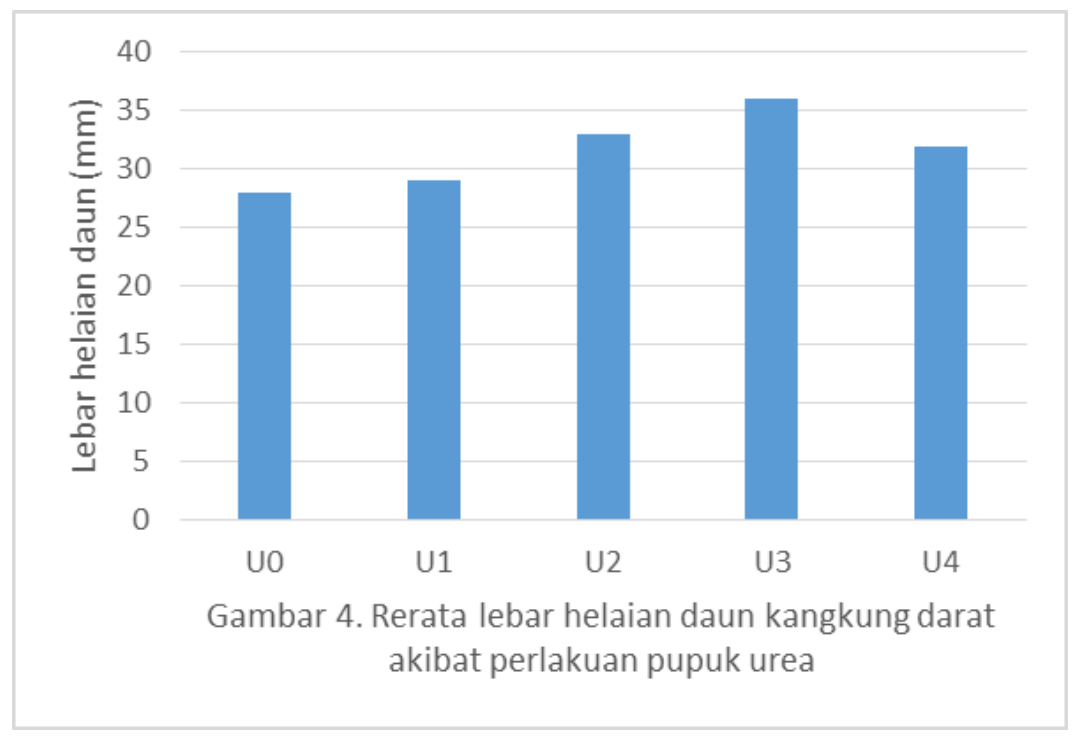

Tabel 4. Hasil analisis sidik ragam pengaruh dosis pupuk urea terhadap lebar helaian daun kangkung darat.

\begin{tabular}{|l|l|l|l|l|l|}
\hline $\begin{array}{l}\text { Sumber } \\
\text { Keragaman }\end{array}$ & DB & JK & KT & F. hitung & $\begin{array}{l}\text { F. tabel } \\
(0,05)\end{array}$ \\
\hline Perlakuan & 4 & 165 & 41,25 & 12,891 & 3,06 \\
\hline Galat & 15 & 48 & 3,2 & & \\
\hline Umum & 19 & 213 & & & \\
\hline
\end{tabular}

Hasil penelitian ini menunjukkan bahwa perbedaan dosis pupuk urea berpengaruh nyata terhadap tinggi batang, panjang helaian daun dan lebar helaian daun kangkung darat. Tinggi batang, panjang helaian daun dan lebar helaian daun tertinggi masing-masing adalah $18 \mathrm{~cm}, 116 \mathrm{~mm}$ dan $36 \mathrm{~mm}$. Sedangkan tinggi batang, panjang helaian daun dan lebar helaian daun terendah masing-masing adalah, $14 \mathrm{~cm}, 106 \mathrm{~mm}, 28 \mathrm{~mm}$. Tinggi batang, panjang helaian daun dan lebar helaian daun teringgi diperoleh pada media tanam yang diberikan perlakuan 1,5 gram pupuk urea per $10 \mathrm{~kg}$ tanah.

Adanya pengaruh nyata pupuk urea terhadap tinggi batang, panjang helaian daun dan lebar helaian daun tanaman kangkung darat dimungkinkan karena pupuk urea merupakan sumber hara nitrogen bagi tanaman. [11] menjelaskan bahwa unsur hara nitrogen sangat diperlukan oleh tanaman dalam jumlah yang banyak. Unsur nitrogen beperan dalam proses fotosintesis, pembentukan asam amino dan protein. Nitrogen merupakan unsur hara essensial dan dibutuhkan dalam jumlah yang banyak sehingga disebut unsur hara makro.

Hasil penelitian ini sejalan dengan hasil penelitian yang dilakukan oleh [13] yang menyimpulkan bahwa pupuk urea sampai $100 \%$ rekomendasi berpengaruh nyata terhadap jumlah 
daun, lingkar batang, jumlah cabang, panjang akar, bobot basah tajuk, bobot basah akar, bobot basah total, bobot kering tajuk, bobot kering akar, dan bobot kering total tanaman alfalfa. Pemberian berbagai dosis nitrogen (pupuk urea) meningkatkan pertumbuhan dan hasil tanaman jagung manis, semakin tinggi dosis nitrogen semakin baik pertumbuhan dan hasil tanaman jagung manis. Pemberian $250 \mathrm{~kg} \mathrm{ha}^{-1}$ pupuk urea menghasilkan produksi panjang lebih baik $(31,44$ $\mathrm{cm})$ dan berat tongkol $\left(10,048\right.$ ton $\left.\mathrm{ha}^{-1}\right)$ dan dosis pupuk yang lebih banyak, dan relatif sama dengan pemberian dosis urea $300 \mathrm{~kg} \mathrm{ha}^{-1}$ [7]. Dosis pupuk urea $450 \mathrm{~kg} / \mathrm{ha}$ menghasilkan rerata bobot kering pipilan jagung per tanaman dan per hektar paling tinggi. Terjadi interaksi antara perlakuan jarak tanam dan dosis pupuk urea terhadap panjang tongkol jagung [9]. Pemberian pupuk urea dengan dosis $135 \mathrm{Kg} / \mathrm{Ha}$ berpengaruh terhadap tinggi tanaman, jumlah cabang dan berat 1000 biji kering kacang tanah [2].

Penggunaan pupuk urea dapat pula dikombinasikan dg pupuk lainnya. Hasil penelitian [10] menunjukkan bahwa komposisi dosis pupuk $285 \mathrm{~kg}$ Urea/ha, $138 \mathrm{~kg} \mathrm{SP-36/ha,} 180 \mathrm{~kg} \mathrm{KCl} / \mathrm{ha}$ memberikan jumlah daun dan jumlah umbi per rumpun bawang merah yang lebih banyak, serta berat segar umbi per rumpun, berat segar umbi per petak dan berat umbi kering simpan per petak yang lebih berat. Tanaman bawang merah merespon sama terhadap peningkatan dosis pupuk Urea, SP$36, \mathrm{KCl}$ pada masing-masing dosis pupuk organik cair Nasa pada semua parameter pengamatan kecuali berat segar umbi per rumpun dan berat umbi kering simpan per rumpun. Penggunaan pupuk kandang sapi, pupuk urea dan kombinasi pupuk kandang sapi dan urea cenderung menghasilkan kandungan minyak asiri jahe merah lebih tinggi daripada perlakuan control [8]. Interaksi pemberian Pugam $\mathrm{T}$ dan urea berpengaruh sangat nyata terhadap parameter tinggi bibit, diameter batang, panjang akar primer dan berat segar bibit kelapa sawit. Hasil tertinggi untuk parameter tinggi bibit umur 4,8 dan 12 MST $(10,57 \mathrm{~cm}, 31,03 \mathrm{~cm}$, dan $35,00 \mathrm{~cm})$, diameter batang umur 4,8 dan $12 \operatorname{MST}(0,57 \mathrm{~cm}, 0,66 \mathrm{~cm}$, dan $0,90 \mathrm{~cm})$, panjang akar primer $(26,08 \mathrm{~cm})$, berat segar bibit (16,68 gram) diperoleh pada perlakuan interaksi pemberian Pugam $\mathrm{T}$ dengan dosis $1.250 \mathrm{~kg} / \mathrm{ha}$ dan Urea dengan dosis 3 gram/liter $\left(\mathrm{P}_{3} \mathrm{~N}_{3}\right)[5]$

\section{KESIMPULAN}

Dalam penelitian ini disimpulkan bahwa: (1) perbedaan dosis pupuk urea berpengaruh nyata terhadap tinggi batang, panjang helaian daun dan lebar helaian daun kangkung darat tetapi tidak berpengaruh nyata terhadap diameter batang kangkung darat (2) Dosis optimum pupuk urea untuk tanaman kangkung darat adalah 1,5 gram per $10 \mathrm{~kg}$ tanah.

\section{DAFTAR PUSTAKA}

[1] Anhar, R., E. Hayati dan Efendi. (2016). Pengaruh Dosis Pupuk Urea terhadap Pertumbuhan dan Produksi Plasma Nutfah padi Lokal Asal Aceh. Kawista. Vol. 1 (1): 30 - 36

[2] Darniati. (2018). Pengaruh Pupuk Urea dan Phosfat terhadap Pertumbuhan dan Hasil Tanaman Kacang Tanah. Agrotropika Hayaati. Vol 5 (1): 54 - 63

[3] Gomez K.A. dan A.A. Gomez. (1995). Prosedur Statistik Untuk penelitian Pertanian Edisi Kedua Penerjemah: Endang Syamsudin dan Justika S. Baharsyah. UI Press. Jakarta.

[4] Hanafiah, K.A. (1991). Rancangan Percobaan Teori dan Aplikasi. PT. Raja Grafindo Persada. Jakarta.

[5] Hertos, M. (2014). Pengaruh Pemberian Pupuk Gambut dan Urea Terhadap Pertumbuhan Bibit Kelapa Sawit (Elaeis guineensis Jacq.) pada Pembibitan Prenursery. Anterior Jurnal. Vol. 13 (2): 139 - 147

[6] Kagoya, T., I.P. Dharma dan I. N. Sutedja. (2018). Pengaruh Pemberian Dosis Pupuk Urea terhadap Pertumbuhan Tanaman Bayam Cabut Putih (Amaranthus tricolor L.). Agroekoteknologi. Vol. 7 (4): 575 - 584

[7] Pernitiani, N.P., Usman dan Adrianton, M. (2018). Pengaruh Pemberian Berbagai Dosis Pupuk Nitrogen terhadap Pertumbuhan dan Hasil tanaman Jagung manis. Agrotekbis. Vol 6 (3): $329-335$

[8] Saputri, L., E.D. Hastuti dan R. Budihastuti. (2018). Respon Pemberian Pupuk Urea dan Pupuk Kandang Sapi terhadap Pertumbuhan dan Kandungan Minyak Atsiri Tanaman Jahe Merah (Zingiber officinale (L.) Rosc var. rubrum). Jurnal Biologi. Vol. 7 (1): 1 - 7

[9] Suwondo, A. dan Paiman. (2016). Pengaruh Jarak Tanam dan Dosis Pupuk Urea terhadap pertumbuhan Gulma dan Hasil Tanaman Jagung (Zea mays L.). Laporan Hasil penelitian. Universitas PGRI Yogyakarta.

[10] Widiastutik, Y., H. Rianto dan Historiawati. (2018). Pengaruh Komposisi Dosis Pupuk Urea, SP-36, KCL dan Pupuk Organik Cair terhadap Hasil Tanaman Bawang Merah (Allium cepa fa. ascalonicum, L.). Vigor. Vol. 3 (2): $61-65$

[11] Winarso, S. (2005). Kesuburan Tanah Dasar Kesehatan dan Kualitas Tanah. Edisi Pertama. Gava Media. Yogyakarta.

[12] Yanti, S. E. F., E. Masrul dan H. Hannum. (2014). Pengaruh Berbagai Dosis dan Cara Aplikasi Pupuk Urea terhadap Produksi Tanaman Sawi (Brassica juncea L) pada 
Tanah Inceptisol Marelan. Agroekoteknologi. Vol 2 (2): 770 - 780

[13] Yuliawati, A Rahayu, dan N Rochman. (2014). Pengaruh Naungan dan Berbagai Dosis Pupuk Urea terhadap Pertumbuhan dan Produksi Vegetatif Alfalfa (Medicago sativa L.). Jurnal Pertanian 5(1): 43-51. 